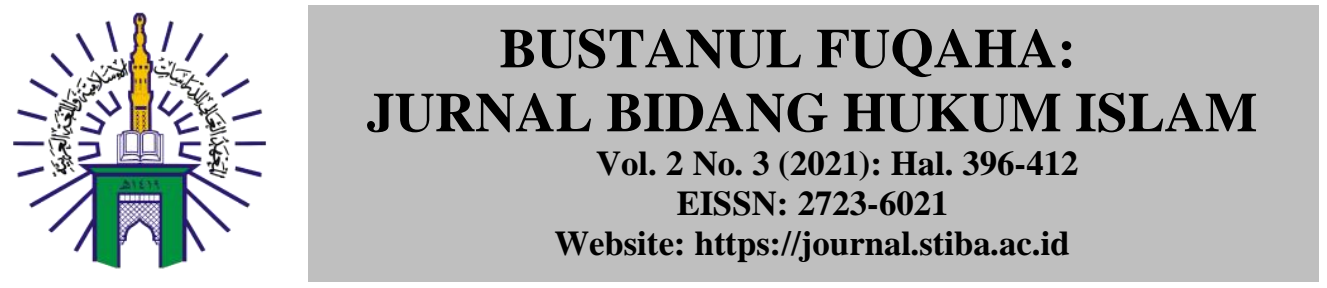

\title{
PERMASALAHAN DAN PENYELESAIAN SENGKETA WAKAF MENURUT UU NO. 41 TAHUN 2004 DAN HUKUM ISLAM (STUDI SENGKETA WAKAF TANAH WAHDAH ISLAMIYAH)
}

\author{
ISSUES AND RESOLUTION OF WAQF DISPUTES \\ ACCORDING TO LAW NO. 41 OF 2004 AND ISLAMIC LAW \\ (STUDY OF WAQF LAND DISPUTES OF WAHDAH \\ ISLAMIYAH)
}

\author{
Muhammad Taufan Djafry \\ Sekolah Tinggi Ilmu Islam dan Bahasa Arab (STIBA) Makassar \\ Email: muhtaufandjafri@stiba.ac.id \\ Askar Patahuddin \\ Sekolah Tinggi Ilmu Islam dan Bahasa Arab (STIBA) Makassar \\ Email: askarfatahuddin@stiba.ac.id
}

\author{
Azwar Iskandar \\ Sekolah Tinggi Ilmu Islam dan Bahasa Arab (STIBA) Makassar \\ Email: azwar@stiba.ac.id

\section{Ambarwati} \\ Sekolah Tinggi Ilmu Islam dan Bahasa Arab (STIBA) Makassar \\ Email: ambarwati@stiba.ac.id
}

\begin{tabular}{|c|c|}
\hline Keywords : & ABSTRACT \\
\hline $\begin{array}{l}\text { Waqf, Dispute, Resolution, } \\
\text { Wahdah Islamiyah }\end{array}$ & $\begin{array}{l}\text { This research aims to find out: (1) the issue of waqf disputes and their } \\
\text { resolution in Indonesia in the view of the Law. No. } 41 \text { of } 2004 \text { and } \\
\text { Islamic law; and (2) the issue of waqf disputes and their settlement in } \\
\text { Wahdah Islamiyah. This research is descriptive-qualitative research } \\
\text { using a juridical-normative approach through field research. The results } \\
\text { showed that: (1) the form of land waqf dispute problems in Indonesia, } \\
\text { including: (a) issues involving holders of legitimate rights to waqf land; } \\
\text { (b) issues related to the reason for rights or proof of acquisition used as } \\
\text { a basis for granting rights; (c) errors/misrepresentation of rights. } \\
\text { Article } 62 \text { of Law No. } 41 \text { of } 2004 \text { on Waqf affirms that the resolution of } \\
\text { disputes is taken through deliberation for consensus. If dispute } \\
\text { resolution through deliberation is unsuccessful, the dispute can be } \\
\text { resolved through mediation, arbitration, or court. As for the review of } \\
\text { Islamic law, the resolution of waqf disputes and other issues in the realm } \\
\text { of Islamic law can be facilitated through litigation and non-litigation. } \\
\text { The existence of peace (al-islah) and deliberation for consensus is } \\
\text { always a priority and is expected to solve problems without causing } \\
\text { other problems (la darara wa la dirära) to achieve the benefit of the }\end{array}$ \\
\hline
\end{tabular}

Muhammad Taufan Djafry, Askar Patahuddin, Azwar Iskandar, \& Ambarwati. 


\begin{tabular}{|c|c|}
\hline & $\begin{array}{l}\text { people in accordance with maqāsid al-syart'ah and justice; (2) Wahdah } \\
\text { Islamiyah faces several problems of land waqf disputes, such as lack of } \\
\text { legal certainty in waqf land ownership, waqf practice by conventional } \\
\text { means, waqf land for sale, claims of waqf land ownership, and no } \\
\text { checking the legality of waqf land. In the settlement of land waqf } \\
\text { disputes, Wahdah Islamiyah directs the resolution of all dispute cases } \\
\text { through two patterns, namely litigation and non-litigation patterns, } \\
\text { which are generally done by familial means or consensus deliberation. }\end{array}$ \\
\hline \multirow{2}{*}{$\begin{array}{l}\text { Kata kunci : } \\
\text { Wakaf, Sengketa, Penyelesaian, } \\
\text { Wahdah Islamiyah }\end{array}$} & ABSTRAK \\
\hline & $\begin{array}{l}\text { Penelitian ini bertujuan untuk mengetahui: (1) Permasalahan sengketa } \\
\text { wakaf dan penyelesaiannya di Indonesia dalam tinjauan Undang-undang } \\
\text { (UU) No. } 41 \text { Tahun } 2004 \text { dan hukum Islam; dan (2) Permasalahan } \\
\text { sengketa wakaf dan penyelesaiannya di Wahdah Islamiyah. Penelitian } \\
\text { adalah penelitian deskriptif-kualitatif dengan pendekatan yuridis- } \\
\text { normatif melalui penelitian lapangan (field research). Hasil penelitian } \\
\text { menunjukkan bahwa: (1) Bentuk permasalahan sengketa wakaf tanah di } \\
\text { Indonesia, di antaranya berupa: (a) Menyangkut pemegang hak yang sah } \\
\text { atas tanah wakaf; (b) Terkait dengan alasan hak atau bukti perolehan } \\
\text { yang digunakan sebagai dasar pemberian hak; (c) Kekeliruan/kesalahan } \\
\text { pemberian hak. Pasal } 62 \text { UU Nomor } 41 \text { Tahun } 2004 \text { tentang Wakaf } \\
\text { menegaskan bahwa penyelesaian sengketa perwakafan ditempuh } \\
\text { melalui musyawarah untuk mufakat. Jika tidak berhasil, sengketa dapat } \\
\text { diselesaikan melalui mediasi, arbitrase, atau pengadilan. Adapun dalam } \\
\text { tinjauan hukum Islam, resolusi sengketa wakaf dan persoalan lain dapat } \\
\text { difasilitasi melalui jalur litigasi dan non-litigasi. Eksistensi perdamaian } \\
\text { (al-ișläh) dan musyawarah untuk mufakat senantiasa menjadi prioritas } \\
\text { dan diharapkan dapat menyelesaikan masalah tanpa memunculkan } \\
\text { persoalan lain (lā d̦arara wa lä dirāra) untuk mencapai kemaslahatan } \\
\text { umat sesuai dengan maqāșid al-syarīah dan keadilan; (2) Wahdah } \\
\text { Islamiyah menghadapi beberapa permasalahan sengketa wakaf tanah, } \\
\text { seperti kurangnya kepastian hukum dalam kepemilikan tanah wakaf, } \\
\text { praktek wakaf dengan cara konvensional, tanah wakaf diperjualbelikan, } \\
\text { klaim pemilikan tanah wakaf, dan tidak ada pengecekan legalitas tanah } \\
\text { wakaf. Dalam penyelesaian sengketa wakaf tanah, Wahdah Islamiyah } \\
\text { mengarahkan penyelesaian semua perkara sengketa melalui dua pola, } \\
\text { yakni pola litigasi dan non litigasi, di mana pada umumnya dilakukan } \\
\text { dengan cara kekeluargaan atau musyawarah mufakat. }\end{array}$ \\
\hline
\end{tabular}

Diterima: 2 September 2021; Direvisi: 4 Oktober 2021; Disetujui: 4 Oktober 2021; Tersedia online: 3 Desember 2021

How to cite: Muhammad Taufan Djafry, Askar Patahuddin, Azwar Iskandar, Ambarwati. "Permasalahan dan Penyelesaian Sengketa Wakaf Menurut UU No. 41 Tahun 2004 dan Hukum Islam (Studi Sengketa Wakaf Tanah Wahdah Islamiyah)", BUSTANUL FUQAHA: Jurnal Bidang Hukum Islam 2, No. 3 (2021): 396-412. doi: 10.36701/bustanul.v2i3.402.

\section{PENDAHULUAN}

Wakaf adalah perbuatan hukum wakif (pihak yang mewakafkan harta benda miliknya) untuk memisahkan atau menyerahkan sebagian harta benda miliknya untuk dimanfaatkan selamanya atau untuk jangka waktu tertentu sesuai dengan 


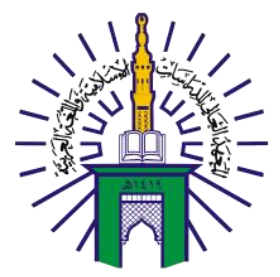

BUSTANUL FUQAHA:

JURNAL BIDANG HUKUM ISLAM

Vol. 2 No. 3 (2021): Hal. 396-412

EISSN: 2723-6021

Website: https://journal.stiba.ac.id

kepentingannya guna keperluan ibadah atau kesejahteraan umum menurut syariat ${ }^{1}$. Dalam Kompilasi Hukum Islam, wakaf bertujuan untuk memanfaatkan harta benda wakif sesuai dengan fungsinya dalam rangka mewujudkan potensi dan manfaat ekonomis harta benda wakif untuk kepentingan ibadah dan untuk memajukan kesejahteraan umum.

Sebelum adanya Undang-Undang (UU) Nomor 5 Tahun 1960 tentang Peraturan Dasar Pokok Agraria (hal yang berkaitan dengan urusan pertanahan) ${ }^{2}$ dan Peraturan Pemerintah Nomor 28 Tahun 1977 tentang Perwakafan Tanah Milik, sebagian besar masyarakat Indonesia melaksanakan wakaf berdasarkan mazhab yang dianut, yaitu Mazhab Syafi'iyah dan adat kebiasaan setempat. Selanjutnya, UU Nomor 1 Tahun 1991 tentang Kompilasi Hukum Islam dan terakhir UU Nomor 41 Tahun 2004 tentang Wakaf, lahir untuk melegalkan institusi wakaf agar memiliki kepastian hukum. Sebelum berlakunya UU tersebut, masyarakat Islam Indonesia masih menggunakan kebiasaan-kebiasaan keagamaan, seperti kebiasaan melakukan perebutan atau pengambilan hukum perwakafan tanah secara lisan atas dasar saling percaya kepada seseorang atau lembaga tertentu ${ }^{3}$.

Dalam hukum Islam, dasar hukum wakaf adalah:

1. Q.s. Āli Imran/3: 92

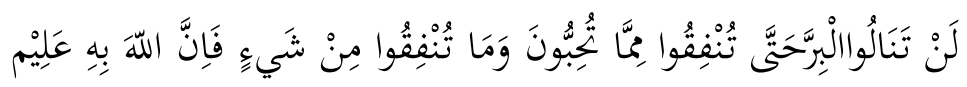

Terjemahnya:

Kamu tidak akan memperoleh kebajikan, sebelum kamu menginfakkan sebagian harta yang kamu cintai. Dan apapun yang kamu infakkan, tentang hal itu sungguh, Allah Maha Mengetahui ${ }^{4}$.

Ayat di atas menjelaskan tentang anjuran untuk menginfakkan harta yang diperoleh untuk mendapatkan pahala dan kebaikan. Ihwal menginfakkan harta yang sangat dicintai, maka ia merupakan syarat meraih kebajikan yang hakiki. Iman perlu dibuktikan dengan pengorbanan. Sehingga, menginfakkan harta yang dicintai membuktikan bahwa kecintaan pada Allah dan agama melebihi kecintaan pada segalanya.

2. Hadis

$$
\begin{aligned}
& \text { عَنْ آَبِي هُرَيْرَة رَضِيَ اللهُ عَنْهُ, عَنِ النَبِي صَلى اللهُ عَلَيْهِ وَسَلَّمَ قَالَ : إِذَ مَاتَ الإنْسَانُ إنْقَطَعَ عَمَلُهُ }
\end{aligned}
$$

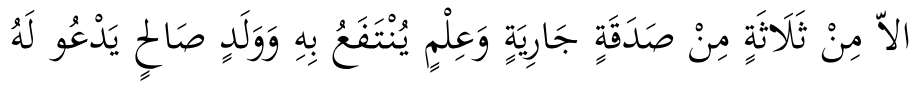

${ }^{1}$ Ditjen Pembinaan Kelembagaan Islam Departemen Agama, Kompilasi Hukum Islam, (Cet. I; Jakarta: Permata Press, 2004), h. 114.

${ }^{2}$ Pusat Bahasa Departemen Pendidikan dan Kebudayaan RI, Kamus Bahasa Indonesia, (Jakarta: Balai Pustaka, 2008), h. 19.

${ }^{3}$ Mardi Candra, Perspektif Hukum Perdata dan Pidana Islam Serta Ekonomi Syariah (Jakarta: Prenada Media, 2018), h. 237.

${ }^{4}$ Kementrian Agama R.I, Al-Qur'ān dan Terjemahnya (Jakarta Selatan: PT. Pantja Cemerlang, 2012), h. 62. 


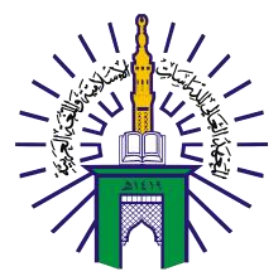

BUSTANUL FUQAHA:

JURNAL BIDANG HUKUM ISLAM

Vol. 2 No. 3 (2021): Hal. 396-412

EISSN: 2723-6021

Website: https://journal.stiba.ac.id

Artinya:

Dari Abi Hurairah ra., dari Rasulullah saw., dia berkata, "Jika seseorang meninggal dunia, maka terputuslah amalannya kecuali tiga perkara (yaitu): sedekah jariah, ilmu yang bermanfaat, dan doa anak yang saleh"s.

Sedekah jariah dalam hal ini adalah sedekah yang pahalanya terus mengalir meski hanya sekali bersedekah dan orang yang bersedekah tersebut sudah meninggal dunia. Sedekah jariah itu tidak lain adalah harta yang diwakafkan. Hal ini dikuatkan melalui riwayat yang berbunyi:

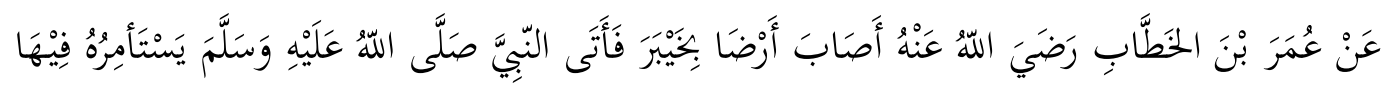

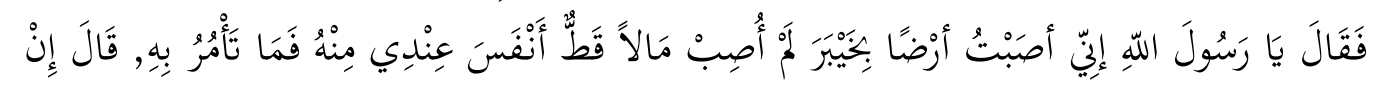

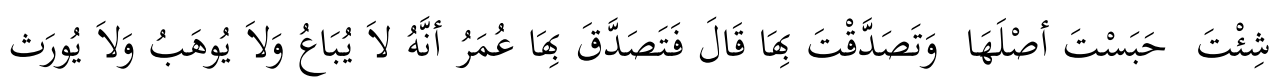

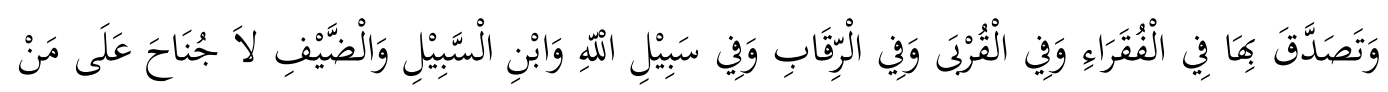

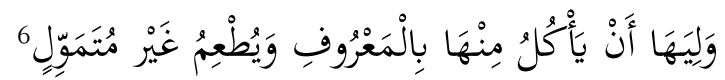

Artinya:

Sesungguhnya Umar ra. mendapatkan sebidang tanah di Khaibar, lalu beliau mendatangi Rasulullah saw. dan meminta nasehat mengenai tanah itu seraya berkata, "Ya Rasulullah, saya mendapatkan sebidang tanah di Khaibar, saya tidak pernah mendapatkan harta lebih baik dari tanah itu. Apakah yang engkau perintahkan kepada saya tentang tanah itu?" Rasulullah saw. menjawab, "Jika engkau berkenan, tahanlah batang pohonnya dan bersedekahlah dengan buahnya." Ibnu Umar berkata, "Maka bersedekahlah Umar dengan buahnya dan batang pohon itu tidak dijual, dihadiakan dan diwariskan. "Dan Umar besedekah dengannya kepada orang-orang fakir, para kerabat, para budak, orang-orang yang berjuang di jalan Allah, ibnu sabīl, dan para tamu. Pengurusnya boleh memakan dari hasilnya dengan cara yang makruf, dan memberikannya kepada yang lain tanpa meminta harganya.

Wakaf dinyatakan sah apabila memenuhi syarat dan rukun wakaf, yaitu:

a. Wakif (orang yang mewakafkan);

b. Mauquf (harta yang diwakafkan);

c. Mauquf 'alaih (pihak yang dituju dari wakaf tersebut);

d. Sigat (lafal dari yang mewakafkan atau pernyataan atau ikrar wakif sebagai suatu kehendak untuk mewakafkan sebagian harta benda) ${ }^{7}$.

${ }^{5}$ Muslim Bin Hajjaj Bin Muslim al-Qusyairi, Sahih Muslim (Cet. VI; Damaskus: al-Maktabah al-Islami, 1987 M/1407 H), h. 264.

${ }^{6}$ Muslim Bin Hajjaj Bin Muslim al-Qusyairi, Sahih Muslim, h. 264.

${ }^{7}$ Mardi Candra, Perspektif Hukum Perdata dan Pidana Islam Serta Ekonomi Syariah, h. 223. 


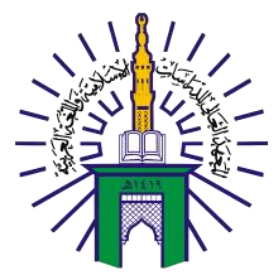

BUSTANUL FUQAHA:

Vol. 2 No. 3 (2021): Hal. 396-412

EISSN: 2723-6021

Website: https://journal.stiba.ac.id

Adapun terkait unsur-unsur wakaf, sesuai dengan Pasal 6 UU Nomor 41 Tahun 2004 tentang Wakaf, yaitu:
a. Wakif;
b. Nāzir;
c. Harta benda wakaf;
d. Ikrar wakaf;
e. Harta benda yang diperuntukan;
f. Jangka waktu wakaf ${ }^{8}$.

Seiring dengan perkembangan zaman, fungsi wakaf menjadi semakin luas sehingga timbul tuntutan adanya sebuah lembaga yang mengurus wakaf secara khusus. Ketika wakaf dipandang sebagai amal sukarela (voluntary) dan memiliki akses terbatas, pengelolaannya diserahkan kepada penerima wakaf (mauquf 'alaihi) atau kepada orang yang ditunjuk oleh pewakaf. Akan tetapi, ketika akses wakaf bertambah luas, timbul permasalahan-permasalahan yang terkait dengan penyimpangan wakaf dan berbagai kendala dalam pengelolaannya, seperti hilangnya tanah wakaf, tanah wakaf terjadi sengketa di pengadilan, tanah wakaf dimiliki oleh orang yang tidak berhak, dan banyak tanah wakaf yang tidak dikelola dengan baik.

Harta wakaf pada prinsipnya adalah milik umat. Dengan demikian, manfaatnya juga harus dirasakan oleh umat. Oleh karena itu, pada tataran ideal, harta wakaf adalah tanggung jawab kolektif dalam menjaga keberadaannya, sehingga keberadaan lembaga yang mengurusi harta wakaf mutlak diperlukan sebagaimana yang telah dilakukan oleh sebagian negara-negara Islam. Indonesia masih terkesan lamban dalam mengurusi wakaf meskipun mayoritas penduduknya beragama Islam. Implikasinya, banyak harta-harta wakaf yang kurang terurus dan bahkan masih ada yang belum dimanfaatkan ${ }^{9}$.

Praktek wakaf di Indonesia masih dilaksanakan secara konvensional dan rentan terhadap berbagai masalah dan tidak sedikit yang berakhir di pengadilan. Kondisi ini diperparah lagi dengan adanya peyimpangan terhadap benda-benda wakaf yang dilakukan oleh oknum yang tidak bertanggung jawab, misalnya dengan memperjualbelikan benda-benda wakaf. Keadaan ini tentu saja berdampak buruk terhadap perkembangan wakaf di Indonesia.

Menyadari tentang keadaan ini, para pihak berwenang memberlakukan beberapa peraturan tentang wakaf untuk dilaksanakan oleh umat Islam di Indonesia. Namun demkian, peraturan-peraturan yang telah dikeluarkan itu dianggap masih belum memadai dalam menghadapi arus globalisasi saat ini, sehingga diperlukan peraturan baru tentang wakaf yang sesuai dengan situasi dan kondisi saat ini. 116.

${ }^{8}$ Ditjen Pembinaan Kelembagaan Islam Departemen Agama, Kompilasi Hukum Islam, h.

${ }^{9}$ Upi Komariah, "Penyelesaian Sengketa Wakaf di Pengadilan Agama", Jurnal Hukum dan Peradilan, no. 2 (2014): h. 118. 


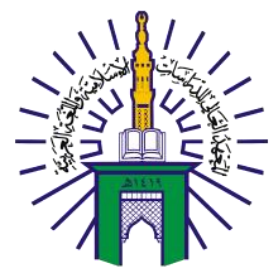

BUSTANUL FUQAHA:

JURNAL BIDANG HUKUM ISLAM

Vol. 2 No. 3 (2021): Hal. 396-412

EISSN: 2723-6021

Website: https://journal.stiba.ac.id

Lahirnya UU Nomor 41 Tahun 2004 tentang Wakaf, memberikan setitik harapan bagi perkembangan dinamis wakaf di Indonesia. UU Nomor 41 Tahun 2004 tersebut mengamanatkan pemerintah untuk memberikan pembinaan terhadap Lembaga wakaf di Indonesia agar dapat berperan dalam meningkatkan kesejahteraan masyarakat umum. Di dalam UU Nomor 41 Tahun 2004 disebutkan bahwa penyelesaian sengketa perwakafan ditempuh melalui musyawarah untuk mencapai mufakat, namun jika penyelesaian sengketa sebagaimana yang disebutkan di atas tidak berhasil sengketa dapat diselesaikan melalui mediasi, arbitrasi, atau pengadilan ${ }^{10}$.

Berdasarkan uraian di atas, peneliti tertarik untuk mengkaji dan menganalisis bagaimana jalan keluar dalam menyelesaikan masalah persengketaan tersebut, dengan mengambil studi kasus pada Ormas Wahdah Islamiyah. Ormas ini dipilih sebagai objek penelitian karena ormas ini tercatat mengelola harta wakaf yang relatif banyak di wilayah Provinsi Sulawesi Selatan. Oleh karena itu, peneliti mengangkat permasalahan sebagai berikut:

1. Bagaimana permasalahan sengketa wakaf dan penyelesaiannya di Indonesia dalam tinjauan UU No. 41 Tahun 2004 dan hukum Islam?

2. Bagaimana permasalahan sengketa wakaf dan penyelesaiannya di Wahdah Islamiyah?

Untuk menjawab rumusan masalah di atas, penelitian ini dilakukan dengan tujuan:

1. Untuk mengetahui permasalahan sengketa wakaf dan penyelesaiannya di Indonesia dalam tinjauan UU. No. 41 Tahun 2004 dan hukum Islam;

2. Untuk mengetahui permasalahan sengketa wakaf dan penyelesaiannya di Wahdah Islamiyah;

Beberapa penelitian dan kajian ilmiah terdahulu telah mencoba untuk mengkaji beberapa permasalahan yang terkait dengan hal tersebut. Nur Fadhilah melakukan penelitian dengan judul "Sengketa Tanah Wakaf dan Strategi Penyelesaiannya." Penelitian ini mengkaji faktor-faktor pemicu dan strategi penyelasaian dari konflik sengketa wakaf, berdasarkan teori resolusi konflik Ralf Dahrendorf dan sudut pandang peraturan-peraturan wakaf ${ }^{11}$. Adapun persamaan dengan tulisan ini yakni sama-sama membahas strategi penyelesaian sengketa wakaf. Izzati Rizqi Annisa mengkaji tentang "Efektivitas Mediasi dalam Penyelesaian Sengketa Wakaf (Studi Kasus Tanah Wakaf Masjid Baitul Qudus di Jalan Gebanganom Kelurahan Genuk Kecamatan Genuk" dalam rangka mengetahui sejauh mana efektivitas mediasi sengketa tanah wakaf dan faktor-faktor penghambat efektivitas mediasi dalam

132.

${ }^{10}$ Ditjen Pembinaan Kelembagaan Islam Departemen Agama, Kompilasi Hukum Islam, h.

${ }^{11}$ Nur Fadhila, "Sengketa Tanah Wakaf dan Strategi Penyelesaiannya," h. 71. 


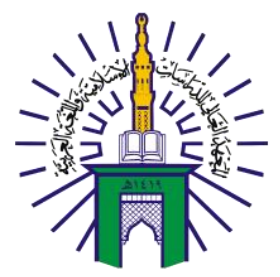

BUSTANUL FUQAHA:

JURNAL BIDANG HUKUM ISLAM

Vol. 2 No. 3 (2021): Hal. 396-412

EISSN: 2723-6021

Website: https://journal.stiba.ac.id

kasus tanah wakaf Masjid Baitul Qudus ${ }^{12}$. Adapun perbedaan dengan penelitian ini yaitu penelitian ini dilakukan di salah satu lembaga yang ada di Makassar yakni Biro Hukum dan Wakaf Tanah Wahdah Islamiyah dengan megkaji bagaimana cara menyelesaikan sengketa tanah yang terjadi.

Selanjutnya, Abdul Rahman Praja Negara melakukan kajian dengan judul "Implementasi Perwakafan Tanah Menurut Undang-Undang Nomor 41 Tahun 2004 Tentang Wakaf (Studi Kasus Sengketa Tanah Wakaf Masjid Ad-Du'a, Bandar Lampung)" dengan tujuan untuk mengetahui kesesuaian UU Nomor 41 Tahun 2004 tentang Wakaf dalam pelaksanannya terhadap proses wakaf tanah Masjid Ad-Du'a, Bandar Lampung dan untuk memahami syarat dan tata cara perwakafan tanah menurut UU Nomor 41 Tahun 2004 tentang Wakaf ${ }^{13}$. Adapun perbedaan dengan penelitian ini yaitu pada objek penelitian di mana penulis mengkaji penyelesaian sengketa menurut Undang-Undang Nomor 41 Tahun 2004 tentang Wakaf dan Hukum Islam di Lembaga Wahdah Islamiyah.

Berdasarkan tujuan yang hendak dicapai, penelitian ini termasuk kategori penelitian deskriptif, yaitu penelitian yang bertujuan menggambarkan atau mendeskripsikan keadaan situasi atau kejadian tertentu untuk kemudian di analisis menggunakan teori-teori yang bersangkutan ${ }^{14}$. Dari sisi pendekatan, penelitian ini menggunakan metode kualitatif dengan pendekatan yuridis-normatif melalui penelitian lapangan (field research). Penelitian lapangan yaitu proses penelitian yang mempunyai suatu periode yang dilakukan berulang-ulang, sehingga keadaan yang sesungguhnya dapat diungkapkan secara cermat dan lengkap, dimulai dengan survey pendahuluan untuk mendeteksi situasi $^{15}$, yaitu mengenai penyelesaian sengketa wakaf menurut UU No. 41 tahun 2004 dan hukum Islam pada sengketa wakaf tanah Wahdah Islamiyah. Sementara pendekatan yuridis-normatif yaitu pendekatan yang dilakukan berdasarkan bahan hukum utama dengan cara menelaah teori-teori, konsep-konsep, asas-asas hukum serta peraturan perundang-undangan yang berhubungan dengan penelitian ini ${ }^{16}$.

Penelitian ini menggunakan data primer dan data sekunder. Data primer yaitu data yang diperoleh langsung dari sumbernya dengan hasil wawancara pihak yang

${ }^{12}$ Izzati Rizqi Annisa, "Efektivitas Mediasi dalam Penyelesaian Sengketa Wakaf (Studi Kasus Tanah Wakaf Masjid Baitul Qudus di Jalan Gebanganom Kelurahan Genuk Kecamatan Genuk)", Skripsi (Semarang: Fak. Syariah dan Hukum UIN Walisongo, 2018), h. 10.

${ }^{13}$ Abdul Rahman Praja Negara, "Implementasi Perwakafan Tanah Menurut Undang-undang Nomor 41 Tahun 2004 tentang Wakaf (Studi Kasus Sengketa Tanah Wakaf Masjid ad-Du'a Bandar Lampung)", Skripsi (Lampung: Fak. Hukum Universitas Lampung Bandar Lampung, 2017), h. 7.

${ }^{14}$ Sumardi Suryabrata, Metode Penelitian, (Jakarta: PT. Grafindo Persada, 2008).h.18

${ }^{15}$ Farouk Muhammad dan Djaali, Metodologi Penelitian Sosial (Bunga Rampai), cet.

I, (Jakarta: PTIK Pres, 2003), h. 100

${ }^{16}$ Lexy J. Moleong, Metodologi Penelitian Kualitatif, (Bandung: PT Remaja Rusdakarya, 2006), h. 114. 


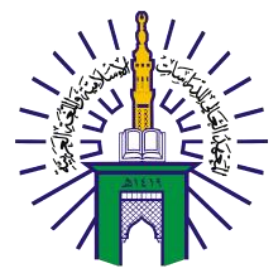

BUSTANUL FUQAHA:

Vol. 2 No. 3 (2021): Hal. 396-412

EISSN: 2723-6021

Website: https://journal.stiba.ac.id

bersangkutan dan hasil pengamatan maupun pencatatan yang sistematis serta dokumentasi. Sementara data sekunder yaitu data yang diperoleh dari berbagai sumber, seperti buku, majalah, jurnal, karya ilmiah, internet, dan berbagai sumber lainnya yang terkait dengan objek itu sendiri ${ }^{17}$. Data dikumpulkan menggunakan teknik wawancara dan studi dokumentasi. Wawancara dilakukan dalam bentuk komunikasi langsung antara peneliti dengan responden, dimana dalam hal ini peneliti mewawancarai Ketua Biro Hukum Wahdah Islamiyah sebagai informan atau narasumber. Sementara untuk studi dokumentasi, peneliti menggunakan catatan-catatan tertulis tentang berbagai kegiatan atau peristiwa pada waktu yang lalu, buku, peneltian, laporan dan lainnya ${ }^{51}$, yang terkait dengan topik penelitian.

Lokasi Penelitian ini adalah kantor Biro Hukum dan Lembaga Wakaf Wahdah Islamiyah, yang berlokasi di Jalan Antang Raya. No. 48, Makassar, Sulawesi Selatan, Indonesia.

\section{PEMBAHASAN}

\section{Permasalahan Sengketa Wakaf dan Penyelesaiannya}

Permasalahan wakaf telah muncul sejak awal sejarah Islam. Permasalahan ini muncul disebabkan oleh perubahan sosial, pergeseran nilai dan tatanan masyarakat, dan tidak adanya bukti tertulis yang menyatakan bahwa status suatu harta sebagai objek wakaf ${ }^{18}$. Banyak tanah wakaf yang tidak mempunyai bukti-bukti, sehingga dapat menyebabkan berbagai kendala dalam pengelolaanya, seperti hilangnya tanah wakaf, tanah wakaf terjadi sengketa di Pengadilan, tanah wakaf dimiliki oleh orang yang tidak berhak, dan banyak tanah wakaf yang tidak dikelola dengan baik, khususnya tanah-tanah yang memiliki nilai produktif.

Secara istilah, "Sengketa" didefinisikan sebagai proses interaksi antara dua orang atau lebih atau kelompok yang masing-masing memperjuangkan kepentingannya atau objek yang sama, yaitu tanah dan benda-benda lain yang berkaitan dengan tanah seperti air, tanaman, tambang juga udara yang berada dibatas tanah yang bersangkutan ${ }^{19}$. Menurut Rachmadi Usman, kata conflict dan dispute keduanya mengandung pengertian tentang adanya perbedaan kepentingan di antara kedua pihak atau lebih, tetapi keduanya dapat dibedakan. Kata conflict sudah diserap ke dalam bahasa Indonesia menjadi konflik, sedangkan kata dispute dapat diterjemahkan dengan sengketa. Sebuah konflik, yakni sebuah situasi di mana dua pihak atau lebih dihadapkan pada perbedaan kepentingan, tidak akan berkembang menjadi sengketa, apabila pihak yang merasa dirugikan hanya

\footnotetext{
${ }^{17}$ Sugiyono, Memahami Penelitian Kualitatif ( Bandung : Alfabeta, 2018 ), h. 37.

${ }^{18}$ Ibrahim Siregar, "Penyelesaian Sengketa Wakaf di Indonesia", Jurnal Pendekatan Sejarah Sosial Hukum Islam, no. 1 (2012): h. 122.

${ }^{19}$ Urip Santoso, Hukum Agraria dan Hak-hak atas Tanah (Jakarta: Prenada Media, 2015), h. 23.
} 


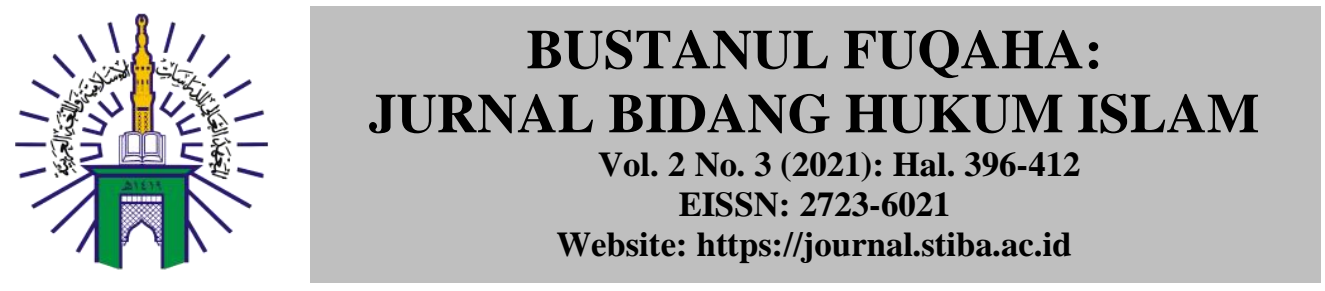

memendam perasaan tidak puas atau keprihatinannya ${ }^{20}$. Secara umum, ada beberapa macam sifat permasalahan dari suatu sengketa tanah, antara lain:

1. Masalah yang menyangkut prioritas dapat ditetapkan sebagai pemegang hak yang sah atas tanah yang berstatus hak atau atas tanah yang belum ada haknya.

2. Bantahan terhadap sesuatu alasan hak atau bukti perolehan yang digunakan sebagai dasar pemberian hak.

3. Kekeliruan/kesalahan pemberian hak yang disebabkan penerapan peraturan yang kurang atau tidak benar.

4. Sengketa atau masalah lain yang mengandung aspek-aspek sosial ${ }^{21}$.

Penyebab-penyebab sengketa atau konflik perwakafan dapat diidentifikasi melalui hal-hal sebagai berikut:

1. Persyaratan yang menyangkut sah dan batalnya wakaf;

2. Tidak jelasnya status ukuran dan luas benda wakaf;

3. Keluarga atau ahli waris tidak mengetahui adanya ikrar wakaf;

4. Wakif maupun ahli warisnya menarik kembali harta benda wakaf baik oleh;

5. Sikap serakah ahli waris;

6. Penyalahgunaan peruntukkan dan fungsi harta benda wakaf oleh nazir ${ }^{22}$.

Sengketa dapat timbul karena ada pihak yang merasakan situasi sosial dan ekonomi yang tidak adil atau hak dan kepentingannya dirugikan. Beberapa teori yang menjelaskan sebab-sebab terjadinya konflik, yaitu:

1. Teori hubungan masyarakat, menjelaskan bahwa sengketa (konflik) disebabkan oleh polarisasi yang terus terjadi, adanya ketidakpercayaan dan rivalitas kelompok dalam masyarakat;

2. Teori negosiasi prinsip, menjelaskan bahwa sengketa (konflik) terjadi karena posisi para pihak yang tidak selaras dan adanya perbedaan-perbedaan di antara para pihak;

3. Teori identitas, menjelaskan bahwa sengketa (konflik) terjadi karena sekelompok orang merasa identitasnya terancam oleh pihak lain;

4. Teori kesalahpahaman, menjelaskan bahwa sengketa (konflik) terjadi karena ketidakcocokan dalam berkomunikasi di antara orang-orang dari latar belakang budaya yang berbeda;

5. Teori transformasi, menjelaskan bahwa sengketa (konflik) dapat terjadi karena adanya masalah-masalah ketidaksetaraan dan ketidakadilan yang mewujud dalam bidang-bidang sosial, ekonomi, dan politik;

\footnotetext{
${ }^{20}$ Nur Fadhila, "Sengketa Tanah Wakaf dan Strategi Penyelesaiannya”, Jurnal Syariah dan Hukum, no. 1 (2011): h. 75.

${ }^{21}$ Maria Sumardjono SW, Mediasi Sengketa Tanah (Jakarta: Penerbit Buku Kompas, 2009), h. 61 .

${ }^{22}$ Izzati Rizqi Annisa, "Efektivitas Mediasi dalam Penyelesaian Sengketa Wakaf (Studi Kasus Tanah Wakaf Masjid Baitul Qudus di Jalan Gebanganom Kelurahan Genuk Kecamatan Genuk", Skripsi, h. 29.
} 
6. Teori kebutuhan manusia, menjelaskan, bahwa sengketa (konflik) dapat terjadi karena kebutuhan atau kepentingan manusia tidak dapat terpenuhi atau terhalangi atau merasa dihalangi oleh pihak lain ${ }^{23}$.

Hal pokok yang sering juga menimbulkan permasalahan perwakafan dalam praktik adalah masih banyaknya wakaf tanah yang tidak ditindaklanjuti dengan pembuatan Akta Ikrar Wakaf. Pelaksanaan wakaf yang terjadi di Indonesia masih banyak yang dilakukan secara agamis atau mendasarkan pada rasa saling percaya. Kondisi ini pada akhirnya menjadikan tanah yang diwakafkan tidak memiliki dasar hukum, sehingga apabila di kemudian hari terjadi permasalahan mengenai kepemilikan tanah wakaf, penyelesaiannya akan menemui kesulitan, khususnya dalam hal pembuktian. Hal lain yang sering menimbulkan permasalahan dalam praktik wakaf di Indonesia adalah dimintanya kembali tanah wakaf oleh ahli waris wakif dan tanah wakaf dikuasai secara turun temurun oleh nazir yang penggunaannya menyimpang dari akad wakaf.

Dalam praktik sering didengar dan dilihat adanya tanah wakaf yang diminta kembali oleh ahli waris wakif setelah wakif tersebut meninggal dunia. Kondisi ini pada dasarnya bukanlah masalah yang serius, karena apabila mengacu pada ketentuan peraturan perundang-undangan, wakaf dapat dilakukan untuk waktu tertentu, sehingga apabila waktu yang ditentukan telah terlampaui, wakaf dikembalikan lagi kepada ahli waris wakif. Namun, khusus untuk wakaf tanah, ketentuan pembuatan akta ikrar wakaf telah menghapuskan kepemilikan hak atas tanah yang diwakafkan sehingga tanah yang diwakafkan tersebut tidak dapat diminta kembali.

Selanjutnya, mengenai dikuasainya tanah wakaf oleh Nazir secara turun temurun dan penggunaannya yang tidak sesuai dengan ikrar wakaf, hal ini dikarekan kurangnya pengawasan dari instansi yang terkait. Ahli waris atau keturunan Nazir beranggapan bahwa tanah tersebut milik Nazir sehingga penggunaannya bebas sesuai kepentingan mereka sendiri karena ketidaktahuan ahli waris Nazir.

Pasal 62 Undang-Undang Nomor 41 Tahun 2004 tentang Wakaf menegaskan bahwa penyelesaian sengketa perwakafan ditempuh melalui musyawarah untuk mufakat. Apabila penyelesaian sengketa melalui musyawarah tidak berhasil, sengketa dapat diselesaikan melalui mediasi, arbitrase, atau pengadilan. Selanjutnya disebutkan dalam penjelasannya, bahwa yang dimaksud dengan mediasi adalah penyelesaian sengketa dengan bantuan pihak ketiga (mediator) yang disepakati oleh pihak yang bersengketa. Dalam hal mediasi tidak berhasil menyelesaikan sengketa, maka sengketa tersebut dapat dibawa kepada badan arbitrase syariah $^{24}$. Dalam hal badan arbitrase syariah tidak berhasil menyelesaikan sengketa, maka sengketa tersebut dapat dibawa ke Pengadilan Agama dan/atau Mahkamah Syariah. Penyelesaian litigasi melalui pengadilan adalah jalan terakhir

${ }^{23}$ Izzati Rizqi Annisa, "Efektivitas Mediasi dalam Penyelesaian Sengketa Wakaf (Studi Kasus Tanah Wakaf Masjid Baitul Qudus di Jalan Gebanganom Kelurahan Genuk Kecamatan Genuk", Skripsi, h. 33.

${ }^{24}$ Fungsi ini dilakukan oleh Badan Arbitrase Syariah Nasional (Basyarnas) Majelis Ulama Indonesia (MUI), yaitu sebuah lembaga arbitrase yang berfungsi dalam penyelesaian sengketa ekonomi Syariah di luar peradilan (Lihat: https://basyarnas-mui.com/profile/3/visi-dan-misi). 


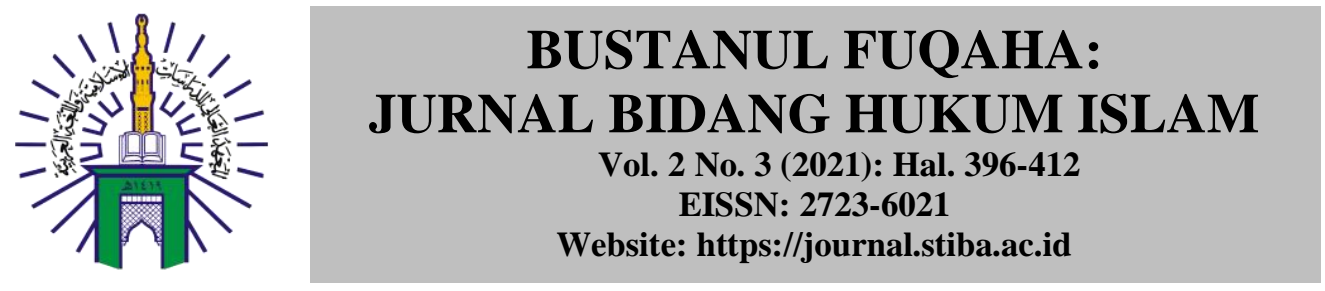

yang dilakukan apabila penyelesaian di luar pengadilan atau non litigasi tidak berhasil menyelesaikan sengketa ${ }^{25}$.

Hal tersebut sejalan dengan Pasal 49 ayat (1) Undang-Undang Nomor 7 Tahun 1989 sebagaimana telah diamandemen dengan Undang-Undang Nomor 3 Tahun 2006 tentang Peradilan Agama, yang menyebutkan "Pengadilan Agama bertugas dan memeriksa, memutus dan menyelesaikan perkara-perkara di tingkat pertama antara orang orang yang beragama Islam, di bidang perkawinan, waris, wasiat, hibah, wakaf, zakat, infak, sedekah; dan ekonomi syariah ${ }^{26}$.

Dalam hal ini, peran negara dengan menggunakan UU Nomor 41 Tahun 2004 tentang Wakaf khususnya tentang penyelesaian sengketa wakaf secara non litigasi adalah untuk menjawab tuntutan akselerasi dan dinamika masyarakat dalam memanage konflik yang volume dan intensitasnya semakin kompleks. Negara memberikan peluang dan kesempatan kepada masyarakat untuk menyelesaikan sengketa sesuai dengan potensi-potensi yang dimiliki melalui institusi penyelesaian konflik yang bersumber dari masyarakat sendiri (folk institution).

Sehubungan dengan hal tersebut di atas, peranan keterlibatan pemerintah (Kementerian Agama Republik Indonesia) dalam melaksanakan pengelolaaan wakaf di Indonesia, memiliki peran yang sangat strategis dan menentukan. Hal ini karena prospek perwakafan di Indonesia memiliki peluang yang sangat positif, baik dari segi kualitas maupun dari segi manfaatnya. Wakaf tidak hanya memiliki nilai ibadah saja akan tetapi diharapkan dapat menjadi wakaf produktif yang sangat perlu dikelola dengan cara profesional, sehingga dapat tumbuh menjadi sector real dalam perekonomian umat, masyarakat dan negara.

Adapun dalam tinjauan hukum Islam, resolusi sengketa wakaf dan persoalan lain dalam ranah hukum Islam dapat difasilitasi mealui jalur litigasi dan non-litigasi. Eksistensi perdamaian (al-iṣlah) dan musyawarah untuk mufakat senantiasa menjadi prioritas. Ketepatan dalam memilih upaya alternatif penyelesaian sengketa wakaf terutama melalui mediasi diharapkan dapat menyelesaikan masalah tanpa memunculkan persoalan lain (lā ḍarara wa lā dirāra). Dinamisasi hukum Islam dituntut melahirkan berbagai upaya solutif terhadap segenap aspek persoalan kehidupan manusia. Demikian pula terkait praktek perwakafan dan beragam wujud problemnya, menuntut adanya penyelesaian. Semua upaya penyelesaian sengketa tersebut bertujuan untuk mencapai kemaslahatan umat sesuai dengan maqāṣid alsyarī'ah dan mewujudkan hukum yang berkeadilan serta menumbuhkan keadilan hukum di tengah masyarakat. Sebagai langkah antisipatif dan untuk meminimalisir sengketa wakaf, seyogianya dipastikan adanya upaya mediasi yang mengedepankan kebajikan dan gerakan legalisasi, baik aset maupun lembaga/pengelola wakaf ${ }^{27}$.

Ketika terjadi sengketa atau persoalan (khusus terkait dengan wakaf) dalam aktivitas kehidupan yang memerlukan suatu penyelesaian, dianjurkan untuk

\footnotetext{
${ }^{25}$ Nur Fadhila, "Sengketa Tanah Wakaf dan Strategi Penyelesaiannya", h. 3.

${ }^{26}$ Si'ah Khosiy'ah, wakaf dan hibah perspektif ulama fiqh dan perkembangannya di Indonesia (Bandung: Pustaka Setia, 2010), h. 82.

${ }^{27}$ Moh. Mahrus, "Konsep al-Maslaha Dalam Penyelesaian Sengketa Wakaf", Skripsi (Probolinggo: Fak. Tarbiyah IAIN Samarinda Kalimantan Timur, 2007), h. 23.
} 


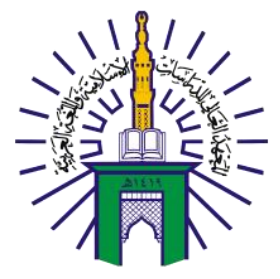

BUSTANUL FUQAHA:

JURNAL BIDANG HUKUM ISLAM

Vol. 2 No. 3 (2021): Hal. 396-412

EISSN: 2723-6021

Website: https://journal.stiba.ac.id

mencari jalan keluar untuk menemukan solusi yang tepat dan benar, bisa dengan kesepakatan damai antara pihak-pihak yang sengketa.

\section{Permasalahan dan Penyelesaian Sengketa Wakaf Tanah Wahdah Islamiyah}

Dalam pengelolaan tanah wakaf, Wahdah Islamiyah mengedepankan asas manajemen untuk menghasilkan output yang baik. Dengan mengedepankan manajemen terbuka dengan prinsip transparansi (pertanggungjawaban yang jelas, terang, dan terbuka) dan akuntabilitas (sistematis di muka umum) serta profesionalitas dalam pengelolaannya. Jika prinsip transparansi dan akuntabilitas ditinggalkan, maka akan membuka peluang terjadinya penyelewengan yang menyimpang dari tujuan organisasi lembaga Wahdah Islamiyah. Dalam sistem pengelolaannya, diperlukan perencanaan (planning), menggerakkan semua potensi (actuating) dan pengawasan (controlling). Adanya prinsip kebersamaan dan tolongmenolong serta nasihat-menasihati dalam kebaikan akan mengalahkan segala tindakan ketidakjujuran, manipulasi dan sebagainya ${ }^{28}$.

Wahdah Islamiyah selalu berupaya melakukan akselerasi dalam pembangunan infrastruktur secara lebih baik, terlebih dalam pemanfaatan tanah wakaf yang sifatnya non konvensional. Potensi wakaf menjadi salah satu sumber infrastruktur umat yang masih lemah, namun Wahdah Islamiyah tetap terus memaksimalkan agar dapat terealisasi. Adapun pembangunan yang dapat dirasakan langsung oleh umat dan masyarakat yang dilakukan oleh Wahdah Islamyah dari wakaf, di antaranya adalah pembangunan masjid, madrasah, pondok pesantren, kuburan, usaha farmasi, usaha pertanian, sarana olahraga memanah dan berkuda sekaligus ibadah tahunan Idul Fitri dan Idul Adha.

Hal yang dilakukan Wahdah Islamiyah agar tanah wakaf dapat meningkatkan produktivitas umat, yaitu dengan pemberdayaan tanah wakaf dari bentuk pengelolaan tradisional konsumtif menjadi profesional produktif. Misalnya, pengelolaan tanah wakaf sebagai sarana dan prasarana dakwah bagi para dai dan masyarakat sekitar, dimana lahan wakaf yang tersedia dikelola atau dijadikan tempat pelatihan para dai dan bercocok tanam yang dapat menghasilkan income atau pendapatan bagi dai-dai tersebut. Namun demikian, dibalik kesuksesan Wahdah Islamiyah dalam mengelola harta wakak untuk kebermanfaatan umat, Wahdah Islamiyah juga menghadapi beberapa sengketa wakaf tanah.

Masalah sengketa wakaf tanah Wahdah Islamiyah muncul disebabkan karena kurangnya kepastian hukum dalam kepemilikan tanah wakaf dan praktek wakaf yang masih mengadopsi cara konvensional yang memungkinkan rentan terjadi masalah dan tidak sedikit yang berakhir di pengadilan. Tanah yang telah diwakafkan juga telah diperjualbelikan oleh oknum-oknum perangkat kelurahan dan oknum perangkat kecamatan. Pada saat Wahdah Islamiyah mengambil alih dan mengelola tanah wakaf tersebut, beberapa oknum masyarakat datang dan mengklaim tanah wakaf tersebut sebagai pemilik dengan memperlihatan sertifikat.

${ }^{28}$ SA (33 tahun), Ketua Biro Hukum dan Advokasi Wahdah Islamiyah Makassar, Wawancara, Makassar, 31 Mei 2019. 




Hal ini kemudian menjadi pemicu munculnya sengketa antara Wahdah Islamiyah dan pihak-pihak yang juga memiliki sertifikat pada lahan dan objek yang sama ${ }^{29}$.

Selain karena faktor di atas, secara umum penyebab terjadinya sengketa wakaf tanah Wahdah Islamiyah adalah:

1. Tidak diadakannya pengecekan awal pada legalitas tanah wakaf tersebut;

2. Tidak melakukan pelaporan data pada kantor kelurahan dan kecamatan;

3. Tidak melibatkan Tim Hukum pada saat penerimaan tanah wakaf, dimana hal ini penting karena untuk memberikan masukan dan pertimbangan sehingga tidak terjadi sengketa lahan wakaf tersebut.

4. Tidak sampainya informasi ke ahli waris dari pewakaf, sehingga tidak mengetahui adanya penyerahan wakaf tanah milik orang tua mereka semasa hidupnya.

5. Kelalaian nazir wakaf yang tidak mengarsipkan atau tidak mengambil segera, serta tidak segera melakukan pengalihan legalitas tanah tersebut ${ }^{30}$.

Kendala yang ditemukan dalam perwakafan tanah Wahdah Islamiyah, menurut pandangan Syamsu Alam sebagai praktisi hukum, "Pada hakikatnya penuangan perwakafan tanah milik dalam UUPA Nomor 5 Tahun 1960, maka secara yuridis merupakan realisasi dari pengakuan terhadap unsur-unsur yang bersandar pada hukum agama, maka dapat disimpulkan bahwa kendala-kendala yang sering kali ditemukan dilapangan yakni:

1. Masih kurangnya pengurus memahami mengenai pendaftaran tanah wakaf dan pensertifikatan tanah wakaf;

2. Pewakif tidak dapat menunjukkan alasan atas tanah yang diwakafkan, oleh karena itu BPN tidak dapat menerbitkan sertifikat atas tanah yang diwakafkan.

Padahal tanah tersebut sudah diikrarkan di KUA oleh pejabat pembuat akta ikrar wakaf;

3. Tidak terlepas pula faktor kendala pada personil di KUA dan BPN yang minim. Sehingga, banyak tanah wakaf tidak tertangani di pengikrarannya dan pendaftaran tanahnya di BPN."

Adapun faktor penghambat yang didapatkan dalam perwakafan tanah Wahdah Islamiyah, faktor penghambat proses pendaftaran tanah wakaf pada lembaga Wahdah Islamiyah, kurangnya informasi hukum terkait tanah wakaf yang diserah terimakan. Status tanah wakaf yang belum jelas kepemilikannya serta batas-batas tanah wakaf tersebut, yang mengakibatkan pada saat pengembalian batas oleh BPN terjadi kesalahan input data dan adanya perubahan wilayah pada objek tanah wakaf tersebut, perubahan terjadi akibat pemekaran wilayah oleh pemerintahan Gubernur dan walikota. Sehingga, data-data tanah wakaf tersebut harus didata ulang dan menjadi pencatatan penting pada buku agenda PPAT kecamatan ${ }^{31}$.

Pemberdayaan dan pengembangan wakaf harus diarahkan kepada wakaf produktif melalui manajemen yang sesuai dengan syariat Islam dengan

\footnotetext{
${ }^{29}$ SA, Wawancara, Makassar, 31 Mei 2019.

${ }^{30}$ SA, Wawancara, Makassar, 31 Mei 2019.

${ }^{31}$ SA, Wawancara, Kantor DPD Makassar, 31 Mei 2019.
} 


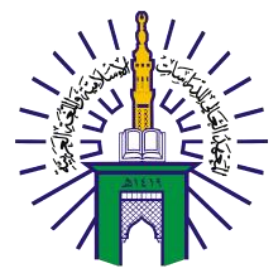

BUSTANUL FUQAHA:

Vol. 2 No. 3 (2021): Hal. 396-412

EISSN: 2723-6021

Website: https://journal.stiba.ac.id

menggerakkan seluruh potensi yang terkait. Beberapa langkah antisipasi yang diakukan oleh Wahdah Islamiyah terhadap sengketa tanah lembaga, yaitu:

1. Melakukan penguasaan fisik lahan tanah wakaf tersebut, sejak dialihkannya ke lembaga Wahdah Islamiyah.

2. Mematuhi segala ketentuan awal dari pewakaf sesuai peruntukannya lahan wakaf tersebut.

3. Mengakomodir segala hal yang berhubungan tentang lahan wakaf menuju kepada wakaf yang produktif.

4. Instan melakukan laporan informasi ke kelurahan, kecamatan dan pewakaf.

Dalam proses penyelesaiaan sengketa wakaf tanah, menurut Syamsu Alam, langkah Wahdah Islamiyah pada umumnya telah sesuai dengan kode etik para advokat, yaitu wajib mengarahkan penyelesaian semua perkara sengketa pada dua pola, yakni (1) Pola litigasi, yaitu penyelesaian perkara sengketa tanah melalui jalur pengadilan dan penetapan keputusan oleh majelis Hakim, dan (2) Non litigasi, yaitu penyelesaian perkara sengketa tanah dengan jalur musyawarah mufakat kedua belah pihak ${ }^{32}$.

Mahkamah Agung berusaha membuat aturan agar perkara sengketa wakaf selesai di ranah non litigasi dengan menggunakan Peraturan Mahkamah Agung Nomor 1 Tahun 2016 tentang Prosedur Mediasi di Pengadilan dan Undang-Undang Nomor 30 Tahun 1999. Salah satunya yakni dengan mengintegrasikan mediasi dalam proses beracara di pengadilan. Harapannya, ketika mediasi dalam sengketa wakaf ini berhasil maka dapat mengurangi beban pengadilan. Konsep sulhu $u^{33}$ (perdamaian) sebagaimana yang tersebut dalam berbagai kitab fikih merupakan satu dokrin utama hukum Islam dalam bidang muamalah untuk menyelesaikan suatu sengketa, dan ini sudah merupakan conditio sine quo non dalam kehidupan masyarakat manapun, karena pada hakekatnya perdamaian bukanlah suatu pranata positif belaka, melainkan lebih berupa fitrah dari manusia.

Adapun proses yang dilakukan Wahdah Islamiyah agar tanah wakaf tersebut secara konstitusional sah di mata hukum, dalam pandangan Syamsu Alam sebagai praktisi hukum dan Ketua Biro Hukum dan Advokasi Wahdah Islamiyah, tentunya mengacu pada UU Nomor 41 Tahun 2004.

Tidak dapat dipungkiri bahwa dalam realitasnya saat ini, beberapa aset wakaf pada lingkungan Wahdah Islamiyah masih dalam proses pengelolaan secara professional dalam rangka memberikan kontribusi dakwah dan berdaya guna untuk peningkatan kualitas hidup masyarakat Islam khususnya dan umat manusia pada umumnya. Oleh karena itu, dengan lahirnya Undang-Undang Nomor 41 tahun 2004

${ }^{32}$ SA, Wawancara, Kantor DPD Makassar, 31 Mei 2019.

${ }^{33}$ Kata al-sulhu atau perdamaian merupakan bentuk masdar dari șalaḥa, yașliḥu, șalhan, yang berarti qat al-munaża'ah atau memutuskan suatu persengkatan atau perselisihan (Lihat: AlMunjid fì al-Lugah wa al-A 'lām.Cet. XXVIII; Beirut: Dār al-Masyriq, 1986). Sedangkan menurut syara' adalah suatu bentuk akad yang dapat menyelesaikan adanya pertentangan atau perselisihan. (Lihat: Imron Abu Amar, Terjemah Fath Al-Qorib, (Kudus: Menara Kudus, 1983), jilid 1, h.254). 


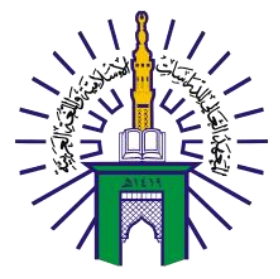

BUSTANUL FUQAHA:

Vol. 2 No. 3 (2021): Hal. 396-412

EISSN: 2723-6021

Website: https://journal.stiba.ac.id

tentang Wakaf, diharapkan kepada semua pihak agar dapat mengembangkan wakaf dalam berbagai aspek, tidak hanya dalam aspek konseptual, namun juga berupaya membuat inovasi dan tindakan kreativitas dalam mengelola harta wakaf agar wakaf dapat dirasakan manfaatnya secara luas bagi seluruh umat Islam dan umat manusia.

Mengingat bahwa pelaksanaan wakaf mengandung nuansa ibadah kepada Allah swt., maka pelaksanaannya tidak boleh lepas dari tuntunan yang digariskan oleh Rasulullah saw. yaitu menciptakan manajemen yang baik guna kemaslahatan umat, melalui tertib administrasi dalam pengelolaan tanah wakaf, penguasaan fisik/objek wakaf, dan legalitas tanah wakaf. Profesionalitas kerja, ketelitian, amanah dan bertanggung jawab sangat penting dimiliki bagi pengurus-pengurus yang ditempatkan pada bidang wakaf. Menerima tanah wakaf tanpa kepedulian aspek hukum yang bisa terjadi, akan dapat berakibat buruk bagi lembaga Wahdah Islamiyah.

\section{KESIMPULAN}

Berdasarkan uraian pembahasan, dapat disimpukan beberapa hal sebagai berikut:

Pertama, permasalahan dari suatu sengketa wakaf tanah di Indonesia, di antaranya: (a) Masalah yang menyangkut pemegang hak yang sah atas tanah wakaf; (b) Masalah terkait dengan alasan hak atau bukti perolehan yang digunakan sebagai dasar pemberian hak; (c) Kekeliruan/kesalahan pemberian hak yang disebabkan penerapan peraturan yang kurang atau tidak benar; (d) Sengketa atau masalah lain yang mengandung aspek-aspek sosial. Selain itu, permasalahan perwakafan dalam praktik juga berupa masih banyaknya wakaf tanah yang tidak ditindaklanjuti dengan pembuatan Akta Ikrar Wakaf, banyak pelaksanaan wakaf yang dilakukan secara agamis atau mendasarkan pada rasa saling percaya, dimintanya kembali tanah wakaf oleh ahli waris wakif dan tanah wakaf dikuasai secara turun temurun oleh nazir yang penggunaannya menyimpang dari akad wakaf. Pasal 62 UndangUndang Nomor 41 Tahun 2004 tentang Dalam wakaf ditegaskan bahwa penyelesaian sengketa perwakafan ditempuh melalui musyawarah untuk mufakat. Apabila penyelesaian sengketa melalui musyawarah tidak berhasil, maka sengketa dapat diselesaikan melalui mediasi, arbitrase, atau pengadilan.

Adapun dalam tinjauan hukum Islam, resolusi sengketa wakaf dan persoalan lain dalam ranah hukum Islam dapat difasilitasi mealui jalur litigasi dan non-litigasi. Eksistensi perdamaian (al-iṣlah) dan musyawarah untuk mufakat senantiasa menjadi prioritas. Ketepatan dalam memilih upaya alternatif penyelesaian sengketa wakaf terutama melalui mediasi diharapkan dapat menyelesaikan masalah tanpa memunculkan persoalan lain (la de darara wa lā dirāara). Semua upaya penyelesaian sengketa tersebut bertujuan untuk mencapai kemaslahatan umat sesuai dengan maqāṣid al-syarīah dan mewujudkan hukum yang berkeadilan serta menumbuhkan keadilan hukum di tengah masyarakat.

Kedua, dibalik kesuksesan Wahdah Islamiyah dalam mengelola harta wakat untuk kebermanfaatan umat, Wahdah Islamiyah juga menghadapi beberapa sengketa wakaf tanah, seperti kurangnya kepastian hukum dalam kepemilikan tanah wakaf dan praktek wakaf yang masih mengadopsi cara konvensional, tanah 


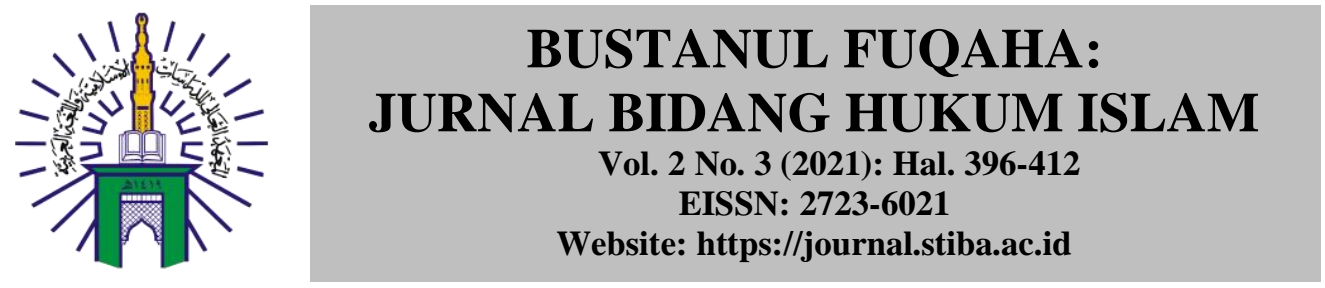

yang telah diwakafkan diperjualbelikan oleh oknum-oknum perangkat kelurahan dan kecamatan, beberapa oknum masyarakat datang dan mengklaim tanah wakaf tersebut sebagai pemilik dengan memperlihatan sertifikat, dan tidak diadakannya pengecekan awal pada legalitas tanah wakaf tersebut. Dalam penyelesaian sengketa wakaf tanah, Wahdah Islamiyah mengarahkan penyelesaian semua perkara sengketa melalui dua pola, yakni: (a) Pola litigasi, yaitu penyelesaian perkara sengketa tanah melalui jalur pengadilan dan penetapan keputusan oleh majelis hakim; dan (b) Non litigasi, yaitu penyelesaian perkara sengketa tanah dengan jalur musyawarah mufakat kedua belah pihak. Selain itu, penyelesaian sengketa wakaf pada lembaga Wahdah Islamiyah dengan berdasar pada hukum Islam pada umumnya dilakukan dengan cara kekeluargaan atau musyawarah mufakat, agar kedua bela pihak melakukan perdamaian di luar pengadilan dan tanpa melibatkan hakim. Pola Penyelesaian dengan cara musyawarah disyariatkan dalam Islam dalam hal apapun itu selama itu tidak melanggar syariat.

\section{DAFTAR PUSTAKA}

Al-Qusyairi, Muslim Bin Hajjaj Bin Muslim. Sahih Muslim. Cet. VI; Damaskus: al-Maktabah al-Islami, $1987 \mathrm{M}$.

Amar, Imron Abu. Terjemah Fath Al-Qorib. Jilid 1; Kudus: Menara Kudus, 1983.

Annisa, Izzati Rizqi. "Efektivitas Mediasi dalam Penyelesain Sengketa Wakaf (Studi Kasus Tanah Wakaf Masjid Baitul Qudus)". Skripsi, Semarang: Fak. Syariah dan Hukum UIN Walisongo, 2018.

Basyarnas-MUI. Visi dan Misi. https://basyarnas-mui.com/profile/3/visi-dan-misi

(Diakses tanggal 11 Oktober 2021).

Candra, Mardi. Perspektif Hukum Perdata dan Pidana Islam serta Ekonomi Ekonomi Syariah. Jakarta: Prenada Media, 2018.

Ditjen Pembinaan Kelembagaan Islam Departemen Agama, Kompilasi Hukum Islam, Cet. I; Jakarta: Permata Press, 2004.

Djaalil, dan Farouk Muhammad. Metodologi Penelitian Sosial. Bunga Rampai. Cet. I; Jakarta: PTIK Pres, 2003.

Fadhilah, Nur. "Sengketa Tanah Wakaf dan Strategi Penyelesaiannya", Jurnal Syariah dan Hukum, no. 1. 2011.

Kementrian Agama RI. Al-qur'an dan Terjemahan. Jakarta Selatan: PT. Pantja Cemerlang, 2012.

Khosiy'ah, Si'ah. Wakaf dan Hibah Perspektif ulama fiqh dan perkembangannya di Indonesia. Bandung: Pustaka Setia, 2010.

Komariah, Upi. "Penyelesaian Sengketa Wakaf di Pengadilan Agama", Jurnal Hukum dan Peradilan, no. 2. 2014.

Louis, Ma'lūf. Al-Munjid fì al-Lugah wa al-A 'lām. Cet. XXVIII; Beirut: Dār alMasyriq, 1986. 


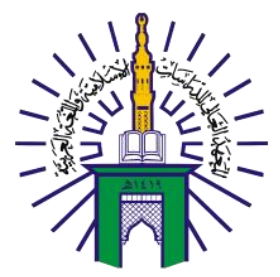

BUSTANUL FUQAHA:

JURNAL BIDANG HUKUM ISLAM

Vol. 2 No. 3 (2021): Hal. 396-412

EISSN: 2723-6021

Website: https://journal.stiba.ac.id

Mahrus, Moh. "Konsep al-Maslaha Dalam Penyelesaian Sengketa”. Skripsi. Probolinggo: Fak. Tarbiyah IAIN Samarinda Kalimantan Timur, 2007.

Moleong, Lexy J. Metodologi Peneitian Kualitatif. Bandung: PT. Remaja Rusdakarya, 2006.

Negara, Abdul Rahman Praja. "Implementasi Perwakafan Tanah menurut Undangundang Nomor 41 Tahun 2004 tentang Wakaf (Studi Kasus Sengketa Tanah Wakaf Masjid ad-Du'a Lampung)". Skripsi. Lampung: Fak. Hukum Universitas Bandar Lampung, 2017.

Pusat Bahasa Departemen Pendidikan dan Kebudayaan RI. Kamus bahasa indonesia. Jakarta: Pusat Bahasa, 2008.

Santoso, Urip. Hukum Agraria dan Hak-hak atas Tanah. Jakarta: Prenada Media, 2005.

Siregar, Ibrahim. "Penyelesaian Sengketa Wakaf di Indonesia”, Jurnal Pendekatan Sejarah Sosial Hukum Islam. No. 1. 2012.

Sugiyono. Memahami Penelitian Kualitatif. Bandung: Alfabeta, 2018.

Sumardjono, Maria SW. Mediasi Sengketa Tanah. Jakarta: Penerbit Buku Kompas, 2009.

Suryabrata, Sumardi. Metode Penelitian. Jakarta: PT. Grafindo Persada, 2008. 